Norgate, in London are: (I) Der Glaube an Gott und die Wissenschaft unserer Zeit, by Professor $\mathrm{W}$. Herrmann (6d.); (2) Die Gottgezeihten in der Alttestamentichen Religion, by Professor B. Duhm (9d.); (3) Die Reform des Strafrechts und die Ethik des Christentums, by Dr. Paul Drews (6d. net); (4) Jesus in Kapernaum, by Dr. Karl
F. A. Lincke; (5) Unbezusstes Christentum, by Dr. Martin Rade (6d.); (6) Herder's Lebenswerk, by Dr. O. Baumgarten (Is. 9d. net); (7) a new edition (the second) of Lic. F. Niebergall's Wie predigen wir dem Modernen Menschen?; and (8) a new edition (the third) of Professor W. Herrmann's Ethik (3s. 9d. net).

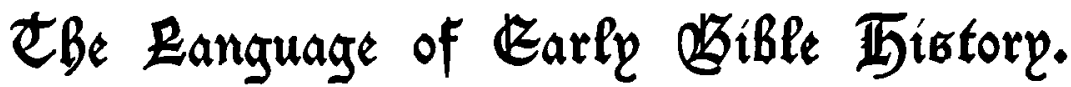

By the Rev. Wentworth Webster, M.A.

MaNy years ago the writer was engaged in the collection of Folk-lore Tales in a language which has few native abstract or collective terms. All such words are evidently borrowed and adopted from later languages. He was careful to take his materials from those who spoke only their native idiom, and knew no other. After a time, when, with considerable difficulty, he had made himself master of some of these tales, was sure that the translation was correct, and had closely crossexamined the narrators, he still found that there was some kind of veil between him and them. Thought did not answer to thought. He was not sure that he had got to the bottom of what they meant; their mental attitude was not the same as his. Suddenly it struck him that they were thinking in the concrete, and he was thinking in the abstract. The key to unlock the difficulty was found. It was not very hard to throw one's mind for the time into the mental attitude of the narrators, to put aside all abstract thoughts and expressions. It was even an amusing experiment; and the tales went on much more merrily, when both narrator and hearer were on the same level or plane of thought.

At first this was only the amusement of Folklore collecting; but on turning to early Bible history, to the study of mythologies and the history of religions, the fact was found to be important and far-reaching. Accidentally, a particular instance of the working of the law of evolution in language had thus practically come home to the writer. To understand fully the thought of those whose only possible expression is the concrete, we have, as it were, to go through a twofold process of translation. We have first to transfer our own abstract thought into the concrete image; then we have to consider how far the concrete representation expresses adequately or inadequately our own abstract thought, and what it means to those who use it. ${ }^{1}$ For instance, we know what we mean by God's omnipotence, omniscience, omnipresence, providence. How would such ideas be expressed by those who thought only in the concrete, before language had attained to the expression or formation of abstract terms? Omnipotence might be expressed by the image of a man with a hundred arms, omniscience or omnipresence by one with a hundred eyes, ${ }^{2}$ the loving providence of God by an image like that of Artemis of Ephesus with a hundred breasts: "Thou satisfiest the desire of every living thing' (Ps $145^{16}$ ). So the abstract notion of good would be expressed only by some object which appeared most desirable to mankind at that time; the abstract notion of evil by the most feared, the most fatal, the most hated object. There was a time when such thoughts could not be expressed otherwise. Later ages, in reporting these things, may mingle more abstract thoughts and expressions with them; but to one who has learned to translate his own abstract thoughts into the concrete the traces of the latter are almost always apparent. $\mathrm{He}$ feels, as it were: 'This must have been originally thought in the concrete only.'

This is often most difficult. What did the figures of the Cherubim over the mercy-seat express to the early Israelites?

${ }^{2}$ In one of my Folk-lore Tales, omniscience was expressed by the mighty local wind which penetrates everywhere; in another, that our Lord had an eye at the back of His head, concealed under His long hair. This was told quite reverently. 
The next point in the upward stage of evolution in thought and language is that in which those physical qualities wherein animals are superior to man are ascribed to some superhuman being; thus omniscience is represented by a hawk-headed man or god; omnipotence by a lion or bull-headed man, or a human-headed lion or bull; and the inscrutable wisdom of God is expressed by a figure like the Sphynx. Then in the next stage the expression and thought become almost purely anthropomorphic.l Thus we read of 'the arm of the Lord'; 'the sword of the Lord'; 'He hath bent His bow.' Even things which appear horrible to us now are deemed pleasing to an anthropomorphic God, as they were to the coarse sensibilities of early man, e.g. the strong rank smell of burning flesh ( $\mathrm{Gn} \mathrm{S}^{21}$ ), passing gradually into incense, and incense into a symbol of prayer (Hos $14{ }^{2}$, He ${ }_{1}{ }^{15}$ ).

Now apply these principles to the narrative of the fall of man in $\mathrm{Gn}$ 2-3. We shall see, I think, that, whatever may be the language in which we have them now, these narratives were originally composed by men who could think and express themselves in the concrete only. In $2^{16.17}$ the desire for knowledge is aroused; but knowledge could be represented to early man only in some concrete form or expression, as one of the most desirable things to early man, a fair and delicious fruit; so evil appears as the most hated and dreaded of objects, the serpent. In $v^{5}$ it is implied that man did not know the difference between good and evil (as an abstract thing), to know that clearly and consciously was beyond his then powers. "The sound (or voice) of the Lord God walking in the garden in the cool (or wind) of the day' is almost exactly as my folk-lorist storytellers might have expressed themselves; they had only one native term for voice and wind. The last verse of 7 : 'They were both naked, the man and his wife, and were not ashamed,' compared with $3^{\tau}$. Is not this the description of unconscious animal instinct just rising into conscious morality? Supposing this to be a narrative going back to a time when thought and language could be expressed only in concrete terms, how are we to interpret and translate this into the thought and expression of to-

1 ' It is characteristic of $\mathrm{J}$ that his representations of the Deity are highly anthropomorphic. - The Book of Genesis, with Introduction and Notes, by S. R. Driver, D.D., p. xx ; Methuen, I904. day? Man is represented as under the dominion of unconscious instinct, in which actions are determined by physical laws and circumstances which he must obey, and over which he has no conscious control. In circumstances like these, if the environment is happy, the creature is happy; he unconsciously follows the law of his being, and is neither troubled nor ashamed. But the great law of progress and evolution is working, as in ages on ages before man came into existence. ${ }^{2}$ Man becomes conscious of the exercise of will and choice, however limited be the exercise of that will and choice. He knows not whether the influences which determine his choice be external or within himself, how far he is still subject to environment and physical laws, how far he can control these to his own benefit; whether external law or internal consciousness should be his best guide? We cannot answer fully all these questions even now; but, whatever value we assign to acts done unconsciously, or through irresistible external determinism, as by instinct, far above all this is the value attached to a voluntary act done by a creature who has power to act or not to act, to give or to withhold, to offer not only compulsory but willing obedience, to approve or to disapprove. Whatever else we may think of the burden, the responsibility, the evils of the action of freewill in a creature not fully capable of controlling his own will-in this direction there is advance. Again, as far as we can see, none of the lower animals lives under the consciousness of the certainty of death. The consciousness, the knowledge, the certainty of this, would come to man with the knowledge of good and evil, and death would seem to him as the supreme evil; the culmination of his knowledge of evil. Another point in which evolution helps us towards interpreting the story of the Fall is this. It is often said, How unjust is the penalty of Adam's sin inflicted on all his posterity! In the ascending stages of evolution there must be some act, the consequence of many series of former acts, one moment in which the evolution of a lower species into a higher becomes definitely fixed; the new species is formed, and all the descendants of this new species become possessors of these

2 Many confuse evolution with the explanations and theories of its processes or working. 'Natural selection,' the 'survival of the fittest,' may be shown to be only partial explanations, and yet evolution may be true. The full knowledge of evolution can be attained only when man is in possession of a synthesis of all knowledge; and this is manifestly beyond his present powers. 
higher qualities, and cannot throw them off, unless by a process of degradation and the reversal of the law of evolution; but the higher and more complex life brings with it greater sensibility to joy and pain, and these must be vastly enhanced as the consciousness and the foresight, or expectation of them become greater and more vivid. Then as to the looking back with yearning on the terrestrial paradise, the animal or bird which has to seek its food by motion, by hunting, by capture, in times of hunger and scarcity might forget in the torture of famine all the joys of motion and of the chase, and long to be like the motionless mollusc affixed to the rock, whose food is brought to it abundantly by the sea-currents without any exertion of its own. Man, as we all know, is not exempt from these tendencies to retrogression. The ascent to higher powers is seldom wholly welcome. "Ye shall be as Gods knowing good and evil.' Yes, but the new powers bring with them greater susceptibilities, greater capacities of suffering as well as of enjoyment. Man's wants and desires increase, and he must constantly toil to satisfy this ever-increasing hunger. 'In the sweat of thy face shalt thou eat bread.' Yet, after all his toil he might wish himself like the birds of the air or the lilies of the field (Mt 625-34).

These are a few of the thoughts which the story of the Fall suggests when read in the light of the evolution of early thought and language. They are most imperfectly expressed. They do not in the least affect the truth of the revelation; that is given to man 'in divers portions and in divers manners,' as man can understand and express it.

\section{Eontributions and Eommenta.}

\section{(Praper in Sleep.}

Is the July Notes of Recent Exposition the interesting question is raised whether we can pray in sleep. There is no a priori reason why we should not. In sleep the mind sometimes acts in the same way as it does in its conscious hours. If, as in the curious instance quoted from the Personal Reminiscences of Mr. Spurgeon, it can then express its thoughts to its fellow-men, why should it not do so to the Supreme Being? The question is one of fact. An example occurs in the Life of John Mackintosh (The Earnest Student, p. 223). He writes in his Diary: 'Tuesday morning-Awoke in prayer for B. M.' (Burn Murdoch). A few days afterwards he refers to this experience in a letter to his friend, 'Next morning you were first in my thoughts, as though I still held your hand; in truth, $I$ awoke in prayer for you.' It may be difficult to decide from such brief entries whether the prayer was offered in the unconsciousness of slumber or in the semi-conscious state which lies between sleeping and waking: at any rate it preceded the wakefulness in which the mind acts consciously and deliberately. Perhaps others can give cases from their reading or experience.

A. FIDDES.

\section{Qвalm xxí. 17.}

THE precise meaning of this verse has been very much disputed, and many scholars are now agreed

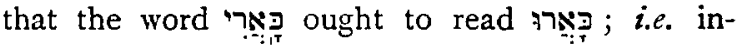
stead of meaning 'as a lion,' the word is a verb, and means 'they pierced or dug through.' The difficulty in connexion with the resp reading has always been that, assuming it to be right, some verb must have slipped out of the text, and sooner than adopt this position, an emendation of the existing text has been suggested. But is it not possible to adopt the words in Hebrew, just precisely as they stand? The verb sit in the Hiphil means 'to surround,' and from the use of the word in Job $19^{6}$, it would appear to be a term

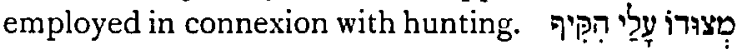
means 'he has encompassed me or entangled me in his net.' May we not take the word to mean the same thing in Ps $22^{17}$ ? Thus, we may keep '

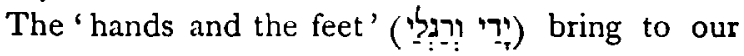
minds the poor beast struggling in the meshes of the net, but unable to free its limbs. So the rendering of the passage we would adopt would be this: "The assembly of wicked ones have thrown round me their net, as though I were a 